\title{
PENINGKATAN HASIL BELAJAR EKOSISTEM MELALUI PENGGUNAAN LABORATORIUM ALAM
}

\author{
NETTY DEMAK H. SITANGGANG \\ YULISTIANA \\ unindralovers@gmail.com \\ 081321849408/085779666047 \\ Program Studi Pendidikan Biologi, Fakultas Teknik, Matematika dan IPA \\ Universitas Indraprasta PGRI
}

\begin{abstract}
Abstrak. Penelitian ini bertujuan untuk mengetahui peningkatan hasil belajar ekosistem melalui penggunaan laboratorium alam klas 7 di SMP negeri 86 Jakarta. Metode penelitian yang digunakan adalah eksperimen dengan penelitian Tindakan kelas (PTK). Penelitian ini dilaksanakan secara saintifik antara peneliti dengan guru IPA dan siswa yang menjadi subjek dari penelitian. PTK dilakukan dua siklus dengan empat kali pertemuan. Kegiatan siklus terdiri dari empat kegiatan pokok yaitu perencanaan (plan), tindakan pelaksanaan (action), observasi (observation), dan refleksi (reflective). Akhir dari pengajaran kelas PTK diberikan tes berbentuk soal dan angket. Hasil data kemudian akan dianalisis dalam bentuk analisis deskriptif, kualitatif dan kuantitatif. Dari data penelitian menunjukkan bahwa penggunaan laboratorium alam meningkatkan hasil belajar biologi siswa dengan pokok bahasan ekosistem kelas 7 SMP Negeri 86 Jakarta Selatan sebesar $80 \%$ peningkatan tersebut diperoleh setelah dua kali siklus tindakan kelas.
\end{abstract}

Kata Kunci: ekosistem, laboratorium alam.

\section{PENDAHULUAN}

Pendidikan adalah usaha sadar dan terencana untuk mewujudkan suasana belajardan proses pembelajaran agar peserta didik aktif mengembangkan potensi dirinyauntuk memiliki kekuatan spiritual keagamaan, pengendalian diri, kepribadian, kecerdasan, akhlak mulia, serta ketrampilan yang diperlukan dirinya,masyarakat bangsa dan negara.Pendidikan bukan sekedar meberikan materi / pengetahuan guru kepada peserta didik, tetapi pendidikan merupakan usaha sadar dan terencana untuk peningkatan aktifitas dan prestasi peserta didik.

Pada zaman sekarang, banyaknya masalah dalam lingkungan masyarakat, bangsa dan negara telah mempengaruhi pola pikir masyarakat.Disinilah peran Guru sebagai tenaga profesional pendidik yang harus mampu memberikan pengetahuan yang baik dan benar serta bermanfaat untuk semua.Pendidikan harus terus berkembang mengikuti perkembangan zaman, dengan arah peserta didik lebihberkualitas dan ivovatif.

Penilaian Guru yang berpatokan nilai kognitif, afektif dan psikomotorik,masih jauh dari nilai maksimal yang diharapkan. Hasil observasi yang dilakukan di kelas VII SMP Negeri 86 Jakarta Selatan menujukknan bahwa proses pembelajaran belum melibatkan peran peserta didik secara menyeluruh.Rendahnya keterlibatan peserta didik dalam pembelajaran ditandai dengan hanya $35 \%$ yang berani menjawab pertanyaan yang diajukan oleh para guru dan 5\% yang berani mengajukan pertanyaan.Taggung jawab peserta didik terhadap pembelajaran yang berupa kesediaan peserta didik untuk memperhatikan,sebenarnya memiliki nilai yang cukup baik.Sebesar $60 \%$ mau memperhatikan penjelasan yang diberikan guru.Namun perhatian ini tidak diiringi keinginan peserta didik untuk mengembangkan potensinya secara mandiri.Hal ini jelas terlihat ketika peserta didik diberi sejumlah soal untuk didiskusikan dan dikerjakan,hanya 
45\% yang bersedia mengerjakan,peserta yang lainya lebih suka bermain dan akhirnya mencontoh peserta yang sudah selesai.

Pembelajaran biologi pada umumnya dilakukan di dalam kelas dengan guru sebagai sumber belajar yang utama menyebabkan pengalaman belajar peserta didik sebatas mendengar dan mencatat penjelasan guru. Akibatnya peserta didik menjadi kurang berinteraksi dengan sumber belajar yang lainnya, sehingga pembelajaran cenderung bersifat tekstual dan menekankan pada penyelesaian materi pembelajaran

Masalah pendidikan dan pelajaran merupakan masalah yang komplek dimana banyak faktor yang mempengaruhinya. Salah Satu faktor yang mempengaruhi yaitu faktor karakteristik peserta didik dan karakter pengajaran. Sehingga metode belajar dapat membangkitkan semangat, minat belajar, mampu menggali, mengembangkan potensi peserta didik yang pada giliranya mampu meningkatkan hasil belajarnya.

Laboratorium merupakan sarana yang sangat besar sekali manfaatnya dalam mendukung keberhasilan guru dalam menyampaikan bahan ajar, sehingga peserta menguasai bahan ajar yang diinginkan terjadi perubahan pada potensi kemapuan peserta dididik lebih baik dari sebelumnya. Tetapi ada kendala yang timbul tidaklah semua memiliki laboratorium, terlebih sekolah-sekolah swasta yang ada di daerah. Agar pelaksanaanna pembelajaran di sekolah yang tidak memiliki laboratorium dapat tetap melaksanakan pengajaran dengan pendekatan ketrampilan proses melalui metode pembelajaran demonstrasi dan eksperimen, sebaiknya memanfaatkan lingkungan sekolah, lebih spesifik lingkungan biotik dan abiotik. Proses belajar mengajar biologi yang menggunakan objek dan persoalan biologi memberikan konsekuen logis bagi siswa untuk berhadapan langsung pada sumber belajar yang alami pada dan sangat nyata, Maka dengan pembelajaran seperti ini diharapkan membutuhkan sikap ilmiah pada siswa serta memberikan pengetahuan terhadap penguasaan konsep bahan ajar.

Pada kurikulum 2013 pembelajaran menerapkan strategi pembelajaran berbasis proyek (Project based Learning), strategi discovery learning, strategi pembelajaran berbasis masalah (Problem besed learning), Pendekatan saintifik yang mana interaksi antara peserta didik dengan lingkungan, harus diberikan untuk bersentuhan langsung dengan objek yang akan atau sedang dipelajari.

Pembelajaran langsung di alam adalah pembelajaran yang dirancang melibatkan peserta didik dalam menggali potensi, informasi dan bertanya, beraktifitas, menemukan, mengumpulkan data dan mampu menganalisis serta membuat kesimpulan sendiri. Kegiatan pembelajaran di alam atau dengan pembelajaran melalui laboraturium alam peserta didik diberi kebebasan dalam mengkontruksi pemikiran dan temuan selama melakukan aktifitas,sehingga peserta didik melakukan sendiri dengan tanpa beban,menyenangkan dan dengan motifasi yang tinggi. Kegiatan ini menunjang sekali pembelajaran kontekstual dengan nilai karakter sebagai refleksi untuk pendidikan Karakter sebagaimana disebutkan Mustari (2011), yaitu nilai: Relegius, jujur, bertanggung jawab, bergaya hidup sehat, disiplin, kerja keras, percaya diri, berjiwa wirausaha, berpikir logis, kritis, kreatif, inovatif, mandiri, ingin tahu, cinta ilmu, sadardiri, patuh pada aturan sosial, respek, santun, demokratis, ekologis, nasionalis, pluralis, cerdas, suka menolong, tangguh, berani mengambil resiko dan berorientasi tindakan.

\section{TINJAUAN PUSTAKA \\ Peningkatan Hasil Belajar}

Hasil belajar peserta didik bukan sekedar dari kepintaran gurudalam menyampaikan materi pembelajaran, akan tetapi peran aktif dan kesadaran peserta didik itu sendiri lah yang bisa meningkatkan hasil belajar. Peserta didik harus selalu diberikan 
motivasi semangat untuk mempunyai kesadaran tinggi dalam meningkatkan hasil belajar. Peningkatan hasil belajar bisa raih dengan adanya kerjasama guru dan peserta didik untuk berkomitmen sadar dan mandiri akan pentingnya belajar dengan baik serta aktif dalam proses pembelajaran.

\section{Pemanfaatan Laboratorium Alam Sebagai Sumber Belajar}

Lingkungan yang selama ini belum banyak dimanfaatkan sebagai sumber belajar ternyata bisa lebih bermanfaat dalam proses pembelajaran.Dengan lingkungan yang bisa dijadikan laboratorium alam, memberikan suasana proses pembelajaran bagi peserta didik yang lebih menyenangkan, dan bisa merefres dari kejenuhan yang selama ini dirasakan peserta didik yang biasa belajar didalam ruang kelas.Pemanfaatan lingkungan khususnya lingkungan sekolah memberikan dampak positif bagi peserta didik dalam proses pembelajaran. Berdasarkan tingkat kekompleksan masalah Observasi lapangan dibedakan menjadi tiga yaitu:

1) Arti penting Laboratorium Alam

Sebagai sumber belajarLaboratorium Alam sangat membantu peserta didik khususnya agar bisa berinteraksi lansung dengan sumber belajar dan media belajar. Penggunaan Laboratorium alam sebagai sumber dan media belajarpeserta didik dalam proses belajar mengajar dapat memungkinkan untuk: a) Meningkatkan hasil belajar, b) Memberi kemungkinan kegiatan yang bersifat mandiri, c) Memberi dasar yang lebih ilmiah terhadap proses pengajaran, d) Memberi informasi atau data yang lebih konkrit, e) Meningkatkan gairah belajar siswa, dan f) Memberi kesempatan yang luas untuk terbentuknya kerjasama antara siswa dengan guru.

2) Pendekatan Laboratorium Alam

Pendekatan Laboratorium Alammerupakan suatu pendekatanpembelajaranyang berusaha untuk meningkatkan keterlibatan peserta didik melalui pendaya gunaan Laboratorium Alam sebagai sumber belajar. Pendekatan ini berasumsi bahwa kegiatan pembelajaran akan menarik perhatian peserta didik jika apa yang dipelajari diangkat dari Laboratorium alam, sehingga apa yang dipelajari berhubungan dengan kehidupan dan berfaidah bagi lingkungannya. Belajar dengan pendekatan Laboratorium alam berarti peserta didik mendapat pengetahuan dan Pemahaman dengan cara mengamati sendiri apa-apa yang ada di Lingkungan sekitar, baik di lingkungan rumah maupun lingkungan sekolah. Pembelajaran dengan pendekatan Laboratorium Alam dapat dilakukan dengan dua cara yaitu: a) Membawa peserta didik ke lingkungan untuk kepentingan pembelajaran. Hal ini bisa dilakukan dengan metode karyawisata, metode pemberian tugas dan lain-lain, b) Membawa sumber-sumber dari tempat lain ke laboratorium alam di sekolah untuk kepentingan pembelajaran. Sumber tersebut bisa sumber asli, seperti penanaman pohon, pembuatan kolam, pemeliharaan hewan dan bisa juga sumber tiruan, seperti model dan gambar.

3). Saling Ketergantungan Dalam Ekosistem

Ekosistem adalah susunan makhluk hidup dan tak hidup. Makhluk hidup dan tak hidup di dunia memiliki jumlah sangat banyak dengan variasi jenis beraneka ragam. Untuk mempermudah pemahaman tentang ekosistem di gunakan berbagai macam istilah sehingga mempermudah mengenal satuan-satuan makhluk hidup dalam ekosistem. Istilah-istilah tersebut sebagai berikut:

1) Individu

Makhluk hidup tunggal dan hidupnya dapat berdiri sendiri.Contohnya, satu tanaman jeruk, seekor hrimau, dan seorangperempuan.

2) Populasi 
Sekumpulan individu makhluk hidup sejenis yang hidup di suatu daerah (habitat) tertentu. Contohnya, beberapa ayam dikandang, serumpun padi di sawah, dan sekelompok anak di halaman.

3) Komunitas

Sekumpulan populasi berbagai jenis makhluk hidup yang hidup bersama di suatu habitat tertentu. Contohnya, populasi ikan, katak, kerbau, dan tanaman padi disawah membentuk komunitas sawah.

4) Lingkungan

Segala sesuatu yang terdapat di sekitar makhluk hidup dan berpengaruh terhadap makhluk hidup itu disebut lingkungan. Lingkungan dapat dibedakan menjadi dua macam, yaitu lingkungan benda tak hidup yang meliputi tanah, batu, air, udara dan cahaya. Lingkungan benda hidup meliputi semua komponen biotik yang berpengaruh terhadap makhluk hidup dalam lingkungan itu.

5) Habitat

Setiap makhluk hidup memerlukan tempat untuk kelangsungan hidupnya. Akan tetapi, tidak sembarang tempat dapat digunakan untuk mendukung kelangsungan hidup itu tetap survive. Misalnya, harimau hidup di hutan yang merupakan habitatnya. Jadi, lingkungan tempat hidup makhluk hidup disebut habitat.

Berdasarkan proses terjadinya, ekosistem dapat dibedakan menjadi dua macam, yaitu:

1) Ekosistem Alamiah

Ekosistem alamiah adalah ekosistem yang terbentuk secara alamiah sebagai akibat pengaruh dari alam sekitarnya. Contohnya, gurun,sungai, danau, hutan, dan padang rumput.

2) Ekosistem Buatan

Ekosistem buatan adalah ekosistem yang dibuat oleh manusia.Contohnya, sawah, ladang kebun, waduk, dan akuarium., Komponen penyusun ekosistem dapat dibedakan menjadi dua macam, yaitu:

a) Komponen Biotik yaitu bagian dari suatu ekosistem yang terdiriatas makhluk hidup. Berdasar fungsi di dalam ekosistem, komponen biotik dapat dikelompokkan menjadi tiga macam, yaituprodusen, konsumen, dan decomposer (pengurai)

b) Komponen abiotik yaitu bagian dari suatu ekosistem yang terdiri dari makhluk tak hidup. Seperti halnya dengan komponen biotik, peran komponen dalam menjamin kelangsungan organisme danterciptanya keseimbangan ekosistem sama besarnya. Komponenabiotik terdiri atas cahaya, udara, air, tanah, suhu, dan mineral. Saling ketergantungan antar komponen ekosistem. Setiap makhluk hidup tidak mampu hidup sendiri tanpa bantuan lingkungan disekelilingnya. Setiap makhluk hidup sangat bergantung pada makhluk hidup lain dan sunber daya alam yang ada disekitarnya yang digunakan untuk keperluan pangan, pertumbuhan, perlindungan dan perkembangbiakan.

Hubungan makhluk hidup dan lingkungan, baik biotik maupun abiotik merupakan hubungan timbal balik yang rumit dan kompleks. Keseimbangan ekosistem dapat terjadi bila ada hubangan timbal balik diantara komponen-komponen ekositem. Semula produsen, herbivora dan karnivora berada pada tempat tertentu. Tumbuhan sebagai produsen yang jumlahnya paling banyak. Apabila ada hal-hal yang mengubah lingkungan maka organisme tersebut tidak akan mengalamiperubahan, tetapi jika jumlah organisme tidak terkendalikan akan membahayakan organisme lainnya. 


\section{METODE}

Penelitian ini dilaksanakan selama \pm 4 bulan. Dimulai pada bulan April sampai Juli 2014. Metode yang digunakan dalam penelitian ini yaitu Penelitian Tindakan Kelas (PTK) kaloboratif(collaborative action reasarsh). Metode penelitian tindakan kelas (clasroom action research) atau bisa disingkat PTK, biasanya dilakukan guna memperbaiki kualitas pembelajaran di kelas dengan guru sebagai peneliti, sehingga pembelajaran di kelas menjadi lebih baik.PTK memiliki karakteristik, yaitu: (1) adanya masalah dalam PTK dipicu oleh munculnya kesadaran pada diri guru bahwa praktek yang dilakukan selama ini di kelas mempunyai masalah yang perlu diselesaikan.

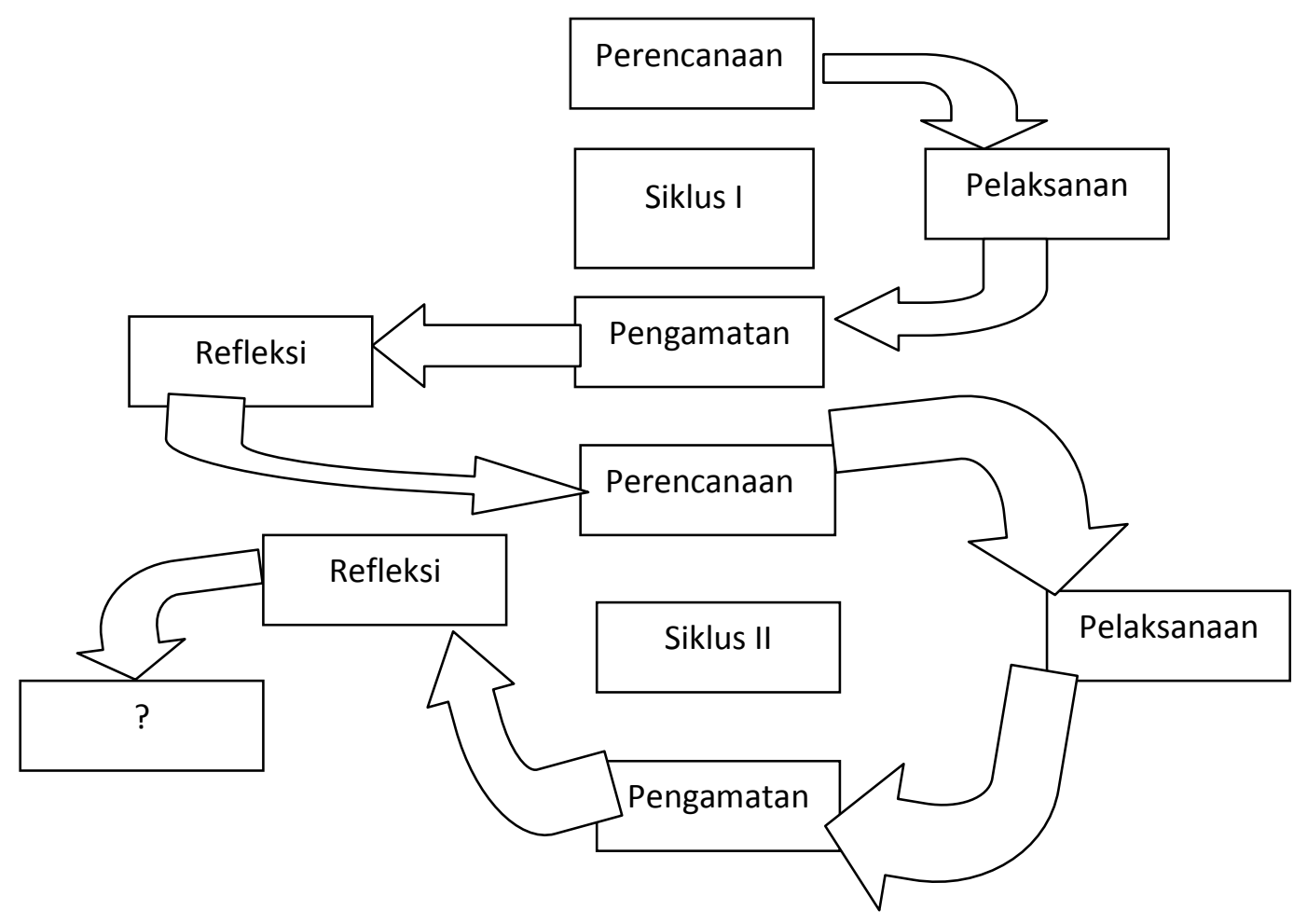

Gambar 1.Model Spiral desain kemmis dan tagart

\section{HASIL PENELITIAN DAN PEMBAHASAN}

\section{Siklus I}

Siklus I berlangsung pada tanggal 7 mei 2014 sampai tanggal 14 mei 2014.Dalam penelitian ini, kegiatan pembelajaran untuk siklus I direncanakan berlangsung 2 x 40 menit. Proses pembelajaran ini didukung oleh Rencana Pelaksanaan Pembelajaran (RPP) yang sesuai dengan pembelajaran laboratorium Alam. Selain RPP, dipersiapkan juga Lembar Kerja Siswa (LKS) dan instrumen tes serta instrumen non tes yang akan dilakukan dengan langkah-langkah pembelajaran menggunakan laboratorium alam.

Akhir siklus I dilakukan evaluasi terhadap hasil belajar biologi peserta didik.Evaluasi tersebut mengunakan instrumen penelitian, yaitu tes akhir siklus1, lembar observasi guru dan siswa,catatan lapangan, serta angket/kuisioner hasil belajar biologi siswa (ranah afektif) 


\section{1) Hasil belajar biologi peserta didik}

Indikator keberhasilan belajar biologi peserta didik berdasarkan pada Kriteria Ketuntasan Minimum (KKM) untuk mata pelajaran biologi kelas VII di SMP Negeri 86 Jakarta adalah 68. Pencapaian KKM kelas VII pada siklus I tertera pada tabel 1.

Tabel 1. Pencapaian KKM Siklus I

\begin{tabular}{|l|l|l|l|}
\hline \multirow{2}{*}{$\begin{array}{l}\text { Pencapaian } \\
\text { KKM }\end{array}$} & Hasil Belajar & \multirow{2}{*}{ Nilai rata-rata } \\
\cline { 2 - 3 } & Frekuensi & Frekuensi Relatif & \\
\hline$\geq 68$ & 15 & 41,66 & \multirow{2}{*}{67,94} \\
\hline$<68$ & 21 & 58,33 & \\
\hline
\end{tabular}

Nilai rata-rata yang diperoleh peserta didik kelas VII pada siklus I adalah 67,94.Hal ini menujukkan bahwa nilai rata-rata peserta didik kelas VII masih berada dibawah KKM.Peserta didik yang telah mencapai KKM sebanyak 15 Peserta didik atau 41,66\%, sedangkan yang belum mencapai KKM sebanyak 21 peserta didik atau 58,33\%. Perolehan tersebut menunjukkan adanya peningkatan hasil belajar peserta didik pada tahap pra siklus.

\section{2) Hasil belajar biologi peserta didik ( ranah afektif)}

Melalui pemberian angket hasil belajar biologi (ranah afektif) pada akhir siklus I ditetapkan skor terendah dan sekor tertinggi. Perolehan rata-rata presentase dari angket hasil belajar biologi perserta didik (ranah afektif) pada siklus I disajiakn pada tabel 2

Tabel 2. Rata-rata Presentasi Penilaian Angket Siklus I

\begin{tabular}{|l|l|}
\hline Angket & Siklus I \\
\hline Rata-rata & 20,97 \\
\hline Presentasi & $59,92 \%$ \\
\hline
\end{tabular}

Diketahui rata-rata hasil belajar biologi peserta didik (ranah afektif) pada siklus 1 sebesar 20,97 dengan rata-rata presentasi sebesar 59,92\%. Hal ini menunjukkan bahwa hasil belajar biologi siswa(ranah efektif) pada siklus ini cukup baik.

\section{Hasil Observasi Guru dan Peserta didik}

Berdasarkan penggunaan lembar observasi pelaksanaan model pembelajaran dengan laboratorium alam didapatkan presentase keterlaksanaan model pembelajaran dengan laboratorium alam pada siklus I. Tabel 3. merupakan persentase kegiatan guru dan peserta didik pada pelaksanaan proses pembelajaran dengan menggunakan hands on activity, dan hasil observasi guru dan peserta didik pada siklus I.

Tabel 3. Keterlaksanaan Pembelajaran Lab Alam

\begin{tabular}{|l|l|l|}
\hline Pertemuan & \multicolumn{2}{|l|}{ Pelaksanaan Pembelajaran Laboratorium Alam } \\
\hline & Oleh Guru & Oleh siswa \\
\hline 1 dan 2 & $70 \%$ & $71 \%$ \\
\hline
\end{tabular}

Berdasarkan cacatan lapangan diketahui tidak semua langkah-langkah model pembelajaran dengan laboratorium alam yang terlaksana secara maksimal. 
Secara umum kegiatan pembelajaran pada siklus I ini mengarah pada hasil yang baik dari pertemuan, namun dalam pelaksanaannya masih belum optimal. Kesimpulan umum sebagai refleksi pada siklus I adalah terjadi peningkatan hasil belajar siswa dari hasil belajar sebelumnya walaupun belum mencapai KKM.

\section{Siklus II}

Siklus II berlangsung pada tanggal 19 mei 2014 sampai tanggal 26 mei 2014.Dalam penelitian ini, kegiatan pembelajaran untuk siklus II berlangsung 2x 40 menit.

Proses pembelajaran ini didukung oleh Rencana Pelaksanaan Pembelajaran (RPP) yang sesuai dengan pembelajaran laboratorium Alam. Selain RPP, dipersiapkan juga Lembar Kerja Siswa (LKS) dan instrumen tes serta instrumen non tes yang akan dilakukan dengan langkah-langkah pembelajaran menggunakan laboratorium alam.

Pertemuan diakhiri siklus pertama, diukur hasil belajar biologi peserta didik dengan memberikan tes akhir siklus dan angket hasil belajar biologi peserta didik (ranah afektif). Selain itu guru juga meminta pendapat peserta didik mengenai kegiatan pembelajaran yang telah berlangsung dengan mewawancarai peserta didik.

Akhir siklus II dilakukan evaluasi terhadap hasil belajar biologi peserta didik. Evaluasi tersebut mengunakan instrumen penelitian, yaitu tes akhir siklus II, lembar observasi guru dan siswa, catatan lapangan, serta angket/kuisioner hasil belajar biologi siswa (ranah afektif)

1) Hasil belajar biologi peserta didik

Indikator keberhasilan belajar biologi peserta didik berdasarkan pada Kriteria Ketuntasa Minimum (KKM) untuk mata pelajaran biologi kelas VII di SMP Negeri 86 Jakarta adalah: 68. Pencapaian KKM kelas VII pada siklus II tertera pada tabel 4 Tabel 4.Pencapaian KKM siklus II

\begin{tabular}{|l|l|l|l|}
\hline \multirow{2}{*}{ Pencapaian KKM } & \multicolumn{2}{|l|}{ Hasil Belajar } & \multirow{2}{*}{ Nilai rata-rata } \\
\cline { 2 - 3 } & Frekuensi & Frekuensi Relatif & \\
\hline$\geq 68$ & 29 & 80,55 & \multirow{2}{*}{81,69} \\
\hline$<68$ & 7 & 19,44 & \\
\hline
\end{tabular}

Nilai rata-rata yang diperoleh peserta didik kelas VII pada siklus II adalah 81,69. Hal ini menujukkan bahwa nilai rata-rata peserta didik kelas VII masih berada dibawah KKM.Peserta didik yang telah mencapai KKM sebanyak 29 Peserta didik atau $80,55 \%$,sedangkan yang belum mencapai KKM sebanyak 7 peserta didik atau 19,44\%. Perolehan tersebut menunjukkan adanya peningkatan hasil belajar peserta didik pada tahap pra siklus.

2.) Hasil belajar biologi peserta didik ( ranah afektif)

Melalui pemberian angket hasil belajar biologi (ranah afektif) pada akhir siklus II ditetapkan skor terendah dan sekor tertinggi. Perolehan rata-rata presentase dari angket hasil belajar biologi perserta didik (ranah afektif) pada siklus I disajikan pada tabel 5

Tabel 5 Rata-rata Presentasi Nilai Angket Siklus II

\begin{tabular}{|l|l|}
\hline ngket & Siklus II \\
\hline Rata-rata & 26,97 \\
\hline Presentasi & $77,06 \%$ \\
\hline
\end{tabular}

Dari Tabel 5 Diketahui rata-rata hasil belajar biologi peserta didik (ranah afektif) pada siklus II sebesar 26,97 dengan rata-rata presentasi sebesar 77,06\%. Hal ini menunjukkan bahwa hasil belajar biologi siswa (ranah efektif) pada siklus ini sudah baik. 


\section{Hasil Observasi Guru dan Peserta didik}

Berdasarkan penggunaan lembar observasi pelaksanaan model pembelajaran dengan laboratorium alam didapatkan presentase keterlaksanaan model pembelajaran dengan laboratorium alam pada siklus II. Tabel 6 merupakan persentase kegiatan guru dan peserta didik pada pelaksanaan proses pembelajaran dengan menggunakan hands on activity, dan hasil observasi guru dan peserta didik pada siklus II.

Tabel 6. Ketercapaian Pembelajaran Lab Alam Siklus II

\begin{tabular}{|l|l|l|}
\hline Pertemuan & \multicolumn{2}{|l|}{ Pelaksanaan Pembelajaran Laboratorium Alam } \\
\hline & Oleh Guru & Oleh siswa \\
\hline 1 dan 2 & $92 \%$ & $96 \%$ \\
\hline
\end{tabular}

Berdasarkan cacatan lapangan diketahui tidak semua langkah model pembelajaran dengan laboratorium alam terlaksana dengan baik.

\section{Tahap Refleksi}

Kegiatan siklus II baik dibandingkan dengan siklus I. Hal ini dapat dilihat dari keterlibatan peserta didik saat kegiatan belajar. Peserta didik lebih aktif dalam melaksanakan pembelajaran yang menggunakan laboratorium alam sebagai media pembelajaran pada pelajaran biologi khususnya materi ekosistem, siswa juga sesudah dapat menggunakan waktu dengan baik.

Pada proses pembelajaran yang diaplikasikan pada siklus II memberikan dampak positif bagi peningkatan hasil belajar biologi peserta didik. Peningkatan hasil belajar biologi peserta didik kelas VII secara secara keseluruhan sebesar lebih dari 50\% dari keseluruhan Jumlah peserta didik yang memperoleh nilai kriteria Ketuntasan Minimal sebanyak 29 siswa dari 36 peserta didik 80,55\%. Penelitian dihentikan pada siklus II, karena indikator keberhasilan berupa peningkatan hasil belajar biologi peserta didik telah tercapai dan sebagian besar langkah model pembelajaran mengunakan laboratorium alam telah terlaksana dengan baik. Setiap langkah-langkah pembelajaran mengunakan laboratorium alam yang akan dilaksanakan pada siklus II, akan didiskusikan oleh peneliti sebagai guru, dan guru biologi sebagai observer sebelum pembelajaran dimulai pada setiap pertemuan sehingga diharapkan seluruh langkah dalam pembelajaran menggunakan laboratorium alam dapat terlaksana secara optimal, Penerapan perbaikan tersebut diharapkan dapat meningkatkan hasil belajar biologi peserta didik.

\section{Pembahasan}

Berdasarkan hasil penelitian telah didapatkan pencapaian KKM pra siklus, siklus I dan siklus II. Selain itu juga didapatkan perbandingan rata-rata presentase prestasi belajar biologi peserta didik (ranah afektif) siklus I dan siklus II, serta perbandingan keterlaksanaan pembelajaran laboratorium alam pada siklus I dan siklus II.

Tabel 7. Perbandingan Pencapaian KKM pra,Siklus I,dan Siklus II

\begin{tabular}{|l|l|l|l|l|l|l|}
\hline \multirow{2}{*}{ KKM } & \multicolumn{3}{|l|}{ Pra Siklus } & \multicolumn{2}{l|}{ Siklus I } & Siklus II \\
\cline { 2 - 7 } & Frekuensi & $\begin{array}{l}\text { Frekuensi } \\
\text { Relatif }\end{array}$ & Frekuensi & $\begin{array}{l}\text { Frekuensi } \\
\text { Relatif }\end{array}$ & Frekuensi & $\begin{array}{l}\text { Frekuensi } \\
\text { Relatif }\end{array}$ \\
\hline$\geq 68$ & 8 & $22.22 \%$ & 15 & $41,66 \%$ & 29 & $80,55 \%$ \\
\hline$<68$ & 28 & 77,77 & 21 & 58,33 & 7 & 19,44 \\
\hline Rata-rata & 64,27 & 67,94 & 81,69 & \\
\hline
\end{tabular}


Pada tabel 7 menujukkan bahwa hasil belajar biologi peserta didik mengalami peningkatan pada setiap siklus, hal ini dapat dapat dilihat pada diagram batang berikut:

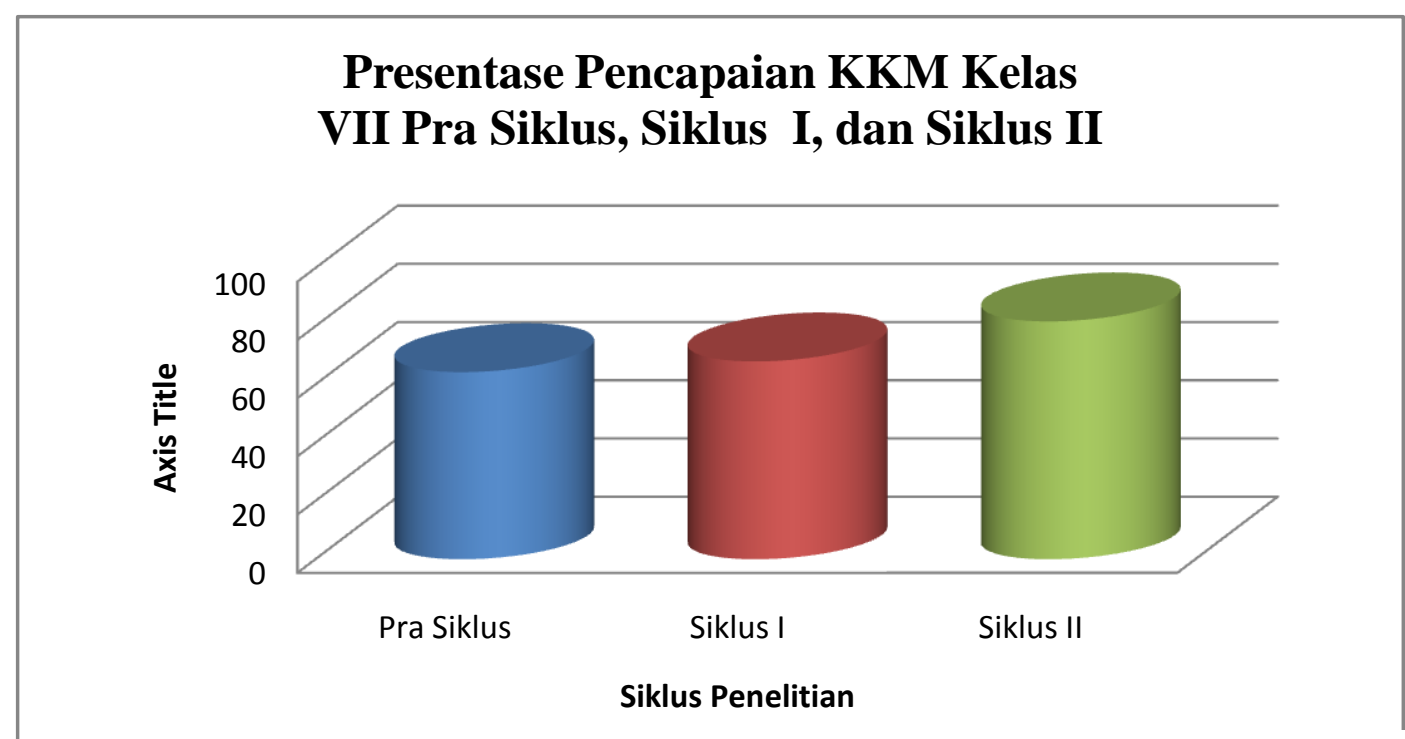

Gambar 1. Persentasi Pencapaian Siklus Pra,Siklus I, dan Siklus II

Gambar 1 Diagram batang presentasi Pencapaian KKM kelas VII Pra (ranah afektif) pada setiap akhir siklus, didapatkan perbandingan rata-rata presentasi hasil belajar biologi siswa (ranah afektif ) siklus I dan siklus II yang dapat dilihat pada Tabel 8.

Tabel 8. Perbandingan rata-rata Presentase Hasil Belajar Biologi Siswa (Ranah Afektif) pada Siklus I dan II

\begin{tabular}{|l|l|l|}
\hline Angket & Siklus I & Siklus II \\
\hline Rata-rata & 20,97 & 26,97 \\
\hline Presentase & 59,92 & 77,06 \\
\hline \hline
\end{tabular}

Rata-rata Presentasi Hasil Belajar Biologi Peserta didik ( Ranah Afektif) pada Siklus I dan Siklus II

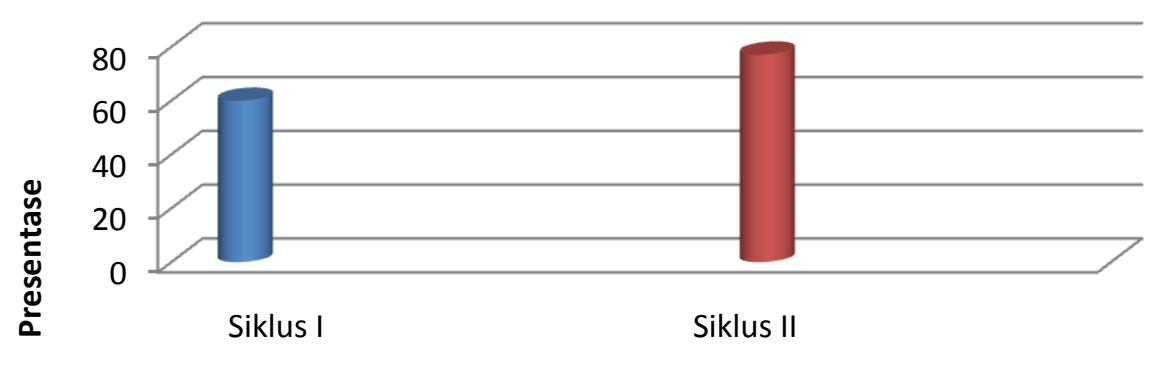

Siklus Penelitian

Gambar 2 Rata-rata Siklus I dan Siklus II

Pada table 8 menunjukkan bahwa hasil belajar Biologi peserta didik ( ranah afektif) pada siklus II mengalami peningkatan dari hasil belajar biologi peserta didik (ranah 
afektif) pada siklus I. Perbandingan rata-rata presentase hasil belajar Biologi peserta didik pada siklus I dan Siklus II dapat dilihat pada diagram batang berikut:

Berdasarkan pengamatan pada proses pembelajaran observasi pembelajaran menggunakan laboratorium alam, didapatkan presentase keterlaksanaan pembelajaran mengunakan laboratorium alam pada Siklus I dan Siklus II.

Tabel 9 merupakan perbandingan presentase kegiatan guru dan peserta didik pada pelaksanaan proses pembelajaran, dengan menggunakan laboratorium alam pada siklus I dan II.

Tabel 9 Perbandingan Presentase keterlaksanaan Pembelajaran Mengunakan Laboratorium Alam pada Siklus I dan Siklus II

\begin{tabular}{|l|l|l|}
\hline \multirow{2}{*}{ Siklus Penelitian } & \multicolumn{2}{|l|}{ Pelaksanaan Pembelajaran Laboratorium Alam } \\
\cline { 2 - 3 } & Oleh Guru & Oleh Peserta didik \\
\hline Siklus I & $70 \%$ & $71 \%$ \\
\hline Siklus II & $92 \%$ & $96 \%$ \\
\hline
\end{tabular}

Pada Tabel 9 Menunjukkan bahwa presentase keterlaksanaan menggunakan laboratorium alam pada siklus II baik kegiatan guru maupun peserta didik mengalami peningkatan dari presentase keterlaksanaan menggunakan laboratorium alam pada siklus I dan siklus II dapat dilihat pada diagram batang di bawah:

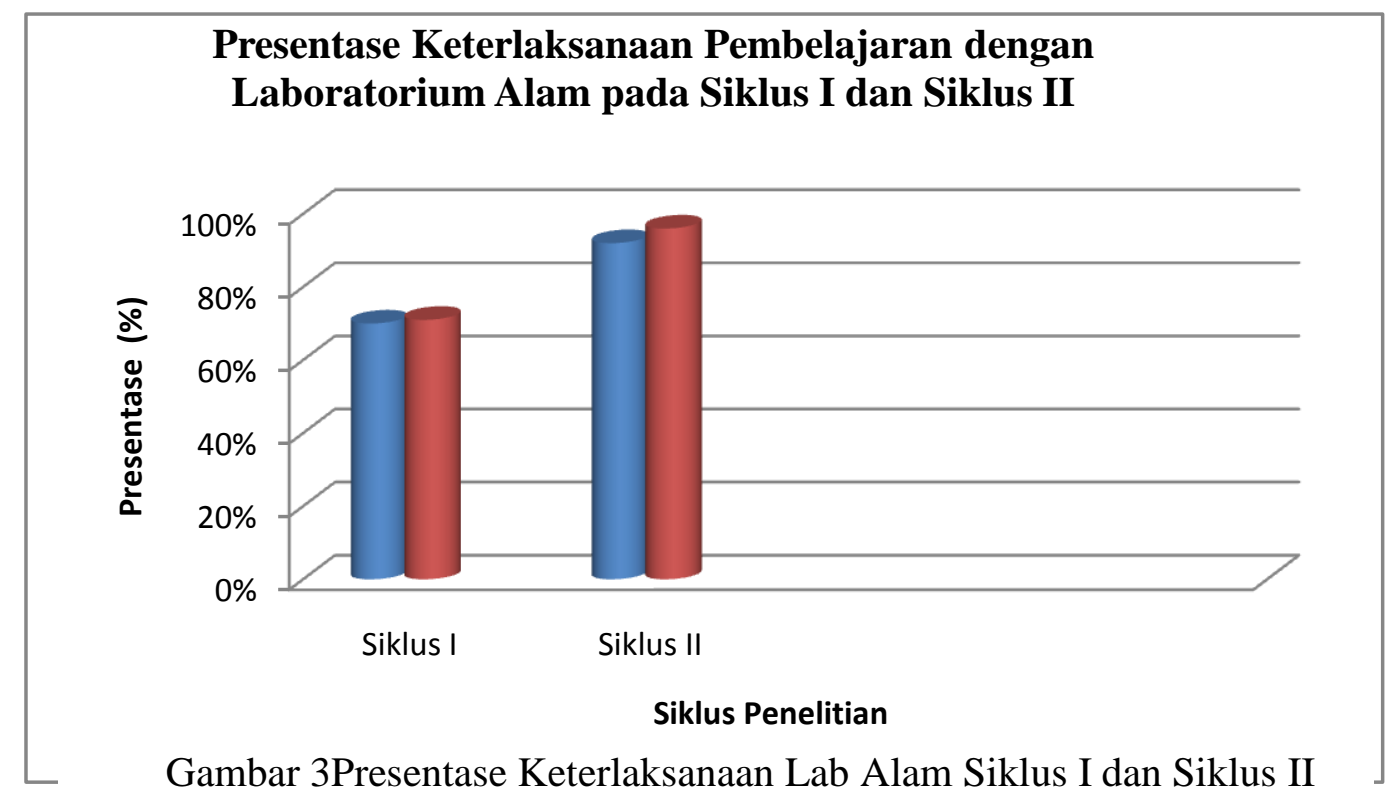

Berdasarkan pengamatan pada siklus I hasil belajar biologi peserta didik mengalami peningkatan hasil belajar biologi. Namun jumlah peserta didik yang mencapai KKM pra siklus hanya sebanyak $67,94 \%$. Hasil ini masih belum memenuhi indikator keberhasilan yaitu sebanyak $80 \%$ peserta didik yang telah memenuhi KKM.

Menurut Trianto (2007:78) model pembelajaran menggunakan laboratorium alam membuat informasi baru akan lebih bermakna. Kurang terlaksanannya model pembelajaran menggunakan laboratorium alam membuat peserta didik kurang bermakna dan tidak mudah diingat oleh peserta didik sehingga hasil belajar yang diinginkan diharapkan belum tercapai. Kurangnya waktu dalam belajar menyebabkan langkah model pembelajaran menggunakan laboratorium alam tidak terlaksana dengan baik. 
Secara umum kegiatan pembelajaran pada siklus I mengarah pada hasil yang lebih baik dari setiap pertemuannya saja belum optimal dalam pelaksanaannya.

Pada siklus I guru tidak memberikan motivasi kepada peserta didik di awal pelajaran, sehingga siswa tidak termotivasi untuk belajar dengan giat. Ini dapat dilihat dari keaktifan peserta didik untuk bertanya dan menjawab pertanyaan dari guru masih sangat mudah.

Selanjutnya berdasarkan pengamatan pada siklus II, Hasil Belajar biologi Peserta didik pada siklus II menghasilkan peningkatan sebesar lebih dari 50\% dari siklus I .Hasil ini telah memenuhi indikator keberhasilan.Peningkatan hasil belajar biologi peserta didik terjadi karena peserta didik telah memahami konsep dari model pembelajaran menggunakan laboratorium alam dengan baik sehingga peserta didik dapat melakukan kegiatan belajar dengan baik.

Guru juga memberikan motivasi yang lebih intensif pada awal pembelajaran kepada peserta didik,peserta didik lebih termotivasi untuk belajar lebih aktif dan interaktf dalam proses pembelajaran sehingga meningkatkan hasil belajar biologi peserta didik.Proses pembelajaran pada siklus II lebih aktif dibandingkan siklus I,Hal ini terlihat dari peserta didik yang menjawab pertanyaan dari guru, menyatakan materi yang belum dikuasai dan mengerjakan LKS. Berdasarkan wawancara akhir siklus II penerimaan siswa terhadap model pembelajaran menggunakan laboraorium alam pada siklus II sudah baik.Selain itu hasil belajar biologi siswa (ranah afektif) juga sudah baik itu terlihat dari rata-rata presentase hasil belajar Biologi peserta didik meningkat.Meningkatnya penerimaan peserta didik terdapat model pembelajaran laboratorium alam dan hasil belajar (ranah afektif) ini karena peserta didiksudah memahami konsep dan tujuan dari proses pembelajaran dengan menggunakan model pembelajaran laboratorium alam pada siklus II lebih tertib dibanding pada siklus I.

Keterlaksanaan Proses pembelajaran dengan menggunakan model pembelajaran laboratorium alam meningkatkan menjadi $80 \%$ aktifitas dari pembelajaran menggunakan laboratorium alam yang dilakukan guru sedangkan aktifitas yang dilakukan peserta didik 94\% Terlaksana sebagian besar langkah pembelajaran menggunakan laboratorium alam terkait erat dengan peningkatan guru dalam mengelola pembelajaran dan mengelola kelas.peningkatan kemapuan ini desebabkan bertambahnya pengalaman guru dalam mengajar, sehingga pembelajaran menggunakan laboratorium alam yang dilakukan sudah lebih baik dibandingkan siklus I. Penerimaan peserta didik terhadap pembelajaran menggunakan laboratotium alam juga semakin lebih baik.Pembelajaran Biologi dengan menggunakan pembelajaran Laboratorium alam dianggap menyenangkan bagi peserta didik, hal ini dapat dilihat dari wawancara dengan peserta didik yang menyatakan peserta didik untuk mengajak guru belajar ke alam dalam kegiatan belajar mengajar karena lebih mengasikkan dan tidak membuat jenuh dan bisa terlibat langsung dengan proses pembelajaran. Dari Penelitian Tindakan Kelas (PTK) diatas menunjukkan keterkaian antara hasil belajar peserta didik(ranah afektif), keterlaksanaan proses pembelajaran hands on activity (ranah psikomotorik) dan hasil belajar biologi peserta didik SMP Negeri 86 jakarta (ranah kognitif). Hal ini sesuai dengan Bloom (1971) dan Asrori (2008:32) bahwa hasil belajar lebih difokuskan pada teori yang membicarakan tiga ranah (The Three Domains of Taxonomi).

\section{PENUTUP \\ Simpulan}

Berdasarkan hasil analisis data penelitian yang telah dilakukan, maka penulis menarik kesimpulan bahwa penggunaan laboratorium alam dapat meningkatkan hasil 
belajar biologi peserta didik dengan pokok bahasan ekosistem kelas VII SMP Negeri 86 Jakarta sebesar $80 \%$. Peningkatan tersebut setelah dua kali siklus tindakan kelas.

\section{Saran}

Berdasarkan hasil penelitian ini maka saran dan harapan yang bisa peneliti sampaikan yaitu guru dapat lebih meningkatkan kualitas dalam mengajar sebagai upaya meningkatkan semangat siswa dalam sistem belajar mengajar Biologi sehingga dapat meningkatkan hasil belajar siswa.

\section{DAFTAR PUSTAKA}

Adullah dkk. 2007. IPA TERPADU SMP dan MTs Jilid 1 B. Jakarta:Erlangga

Bloom, Benyamin S, Max D, Englehart, Edward J, Furst, Walker H.Hill, dan David R. Krathwohll. 2001. Taxonomy of Educational Objective HANDBOOK i: Cognitive Domain. New York: Addison Wesley Longman Inc.

Fachrul.2008. Metode Sampling Bioekologi.Jakarta: PT Bumi Aksara

Hamalik, Oemar. 2005. Proses Belajar Mengajar. Jakrta: Bumi Aksara.

Mustari. 2011. Nilai Karakter. Yogyakarta: LaksBang PRESSindo

Supardi, U.S. 2013. Aplikasi Statistik dalam Penelitian . Edisi Revisi. .Jakarta: Change Publication.

Takari.2007.Kamus Visual Tumbuhan.Bandung: Epsilon Group. 